\title{
Assessment of viable fungi in indoor air: a case study from Tagore's residence at Jorasanko, India
}

\author{
Subarna Bhattacharyya ${ }^{1 *}$, Debleena Mukherjee ${ }^{2}$, Paushali Sarkar ${ }^{2}$, \\ Sreya Ghosh ${ }^{2}$, Barnali Samaddar ${ }^{2}$, Punarbasu Chaudhuri ${ }^{3}$ \\ ${ }^{1}$ School of Environmental Studies, Jadavpur University, 188 Raja S. C. Mullik Road, Kolkata, India \\ ${ }^{2}$ Department of Environmental Studies, Rabindra Bharati University, Kolkata, India \\ ${ }^{3}$ Department of Environmental Science, University of Calcutta, India \\ *E-mail address: barna_kol@yahoo.com
}

\begin{abstract}
Indoor environment is significant with respect to human health especially if it is concerned when the building is v. Aim of very old. In the present study was to assess the presence of airborne fungi at an old building in Kolkata India where lots of tourists are exposed every day. Residence of famous Nobel laureate poet Rabindranath Tagore (built in the 18th century and presently used as a famous museum) in Kolkata, West Bengal was selected for this study and the indoor fungi from different room of the museum were assessed by using exposure plate technique. Humidity, temperature, wind speed and illuminance were also measured by hygrometer, thermometer anemometer and lux-meter respectively. The fungal species isolated from the air samples of different rooms were Aspergillus sp., Penicillium sp., Paecilomyces sp., Trichoderma sp, Alternaria $s p$ Verticillium sp, Fusarium sp, Cladosporium sp, Yeast, Curvularia sp. and Helminthosporium sp. among them, Aspergillus sp. (71.4\% at monsoon at library), Penicillium sp (57\% at summer at library), Paecilomyces sp.(91\% at monsoon at manuscript room) are mostly dominated pathogens, which may harm the workers and visitors of the museum. No significant correlation among colony forming unit of fungi with illuminance, wind speed and temperature in the tested indoor environment was noted whereas, the humidity in indoor environment played a crucial $(\mathrm{P}<0.05)$ role. Round the year humidity control may be required for maintaining healthy environment.
\end{abstract}

Keywords: Tagore's residence; viable fungi; indoor environment

\section{INTRODUCTION}

The Tagore's residence at Jorasanko, north of Kolkata, West Bengal, India, is the ancestral home of the Tagore family. It is currently located on the Rabindra Bharati University campus at 6/4 Dwarakanath Tagore Lane Jorasanko, Kolkata. This house is two hundred years old (built in the 18th century) is situated at the banks of the Hooghly River at $20 \mathrm{ft}$ above sea level. The building is declared as "Heritage building" which means any building of one or more premises or any part thereof and/or structure and/or artifact which requires conservation and / or preservation for historical and / or architectural and / or artisanary and /or aesthetic and/or cultural and/or environmental and/or ecological purpose and includes such portion of land adjoining such building or part thereof as may be required for fencing or covering or in any manner preserving the historical and/or architectural and/or aesthetic and/or cultural value of such building [1]. Presently most of the heritage buildings are used as museum, universities and office purpose. The places are very common and popular tourist spot also. In Australia 2.7 million and 10.9 million international and domestic 
tourists visit annually in different heritage place of the continent [2]. Usually visitors stay at indoor environment when they visit museum. Nearly 55 million people visit in the British Museum annually. Quality of indoor air is a matter of great interests not only because visitors spend their time inside the buildings but in particular indoor environment the fungi are very common contaminant dangerous for public health [3]. Fungi and moulds are biological hazards that are ubiquitous both in the communal and occupational environments [4]. Numerous studies have demonstrated at heritage building ambient. Common moulds such as Alternaria, Aspergillus, Penicillium, Mucor, Drechslera, Cladosporium, Fusarium and Ulocladium occur frequently in almost in both outdoor and indoor environments causing various diseases like rhinitis, dermatitis and allergic asthma [5, 6]. Mycotoxin-producing fungi are not uncommon in residential buildings. Miller et al. found evidence of mycotoxin production in three homes containing Aspergillus fumigates [7]. Trichothecene mycotoxins have also been isolated from the ventilation systems of three "sick" buildings in Montreal [8]. Nevertheless Fungi produce serious damage in historic materials, which are decomposed from the impact of specific enzymes, cellulases, proteases, ligninases, and organic acids. Pigmentation and physical damage commonly known as foxing in materials are a common phenomenon of bio-deterioration [6]. Fungi also play a considerable role for the deterioration of cultural heritage. Exhibits like paintings, textiles, paper, jute, parchment, leather, oil, casein, glue and other materials using for historical art objects act as the fungus growing media in indoor environment [9]. In indoor environment the fungi are dangerous because they can able to grow in lower relative humidity $(\mathrm{RH})$ than bacteria. Over the pass twenty years, various air-conditioning systems have been installed in buildings to control environmental conditions and to prevent the development of biological agents. It is established that stabilize relative humidity, temperature, moisture content control the fungal growth of any indoor environment [10]. In tropical climate where $\mathrm{RH}$ is high, temperature fluctuates from 38 to $24^{\circ} \mathrm{C}$ and prevalent wind disperses spores, grows in their suitable condition and belongs dormant on the surfaces of objects. Dispersion of spores is the main cause of contamination in the environment [11].

Our study was focused on the sampling of viable fungal species in indoor environment of Tagore's residence at Jorasanko, Kolkata, India. As the city is close to the Tropic of Cancer and is situated on the banks of the River Hooghly at an elevation of $20 \mathrm{ft}$ above sea level. The climate is warm and humid throughout the year. The temperature fluctuates between 24 and $38^{\circ} \mathrm{C}$ during summer and $12-27^{\circ} \mathrm{C}$ in winter. Average rainfall is about $1,582 \mathrm{~mm}$ per annum (June-September). The particular study site is supposed to be an ideal place for fungal contamination. The study was aimed to assess the viable fungal load in the different room of the building and establish relationship among meteorological parameters.

\section{MATERIAL AND METHODS}

The viable micro-fungi will be sampled by sediment method; various agar plates specific for fungi like malt extract, potato dextrose, was distributed in several places inside the cupboard and exhibition room and they were left open for $5 \mathrm{~min}$ and placed open at approximately one meter above the floor [12].The colony forming unit (CFU) number per cubic meter was estimated according to formula [13].

$$
\mathrm{N}=5 \mathrm{a} \times 104(\mathrm{bt})^{-1}
$$

Where, $\mathrm{N}=$ microbial $\mathrm{CFU} \mathrm{\textrm {m } ^ { - 3 }}$ of indoor air, $\mathrm{a}=$ number of colonies per Petri dish, $\mathrm{b}=$ dish surface, in square centimeters, and $\mathrm{t}=$ exposure time, in minutes. 
Classification of isolated fungi was made with accordance to the current procedures. After incubation at $27^{\circ} \mathrm{C}$ for three days quantitative analysis and morphological evaluation of fungal colonies were carried out, and depending on the nature of the fungi cultures the plates were incubated for up to 14 days to allow identification. The raw counts of colonies on the agar plates were adjusted by reference to statistical scaling tables applying to the particular sampler. The cultured fungi were identified from macroscopic and microscopic characteristics, and biochemical tests were appropriate. Temperature, humidity and wind speed were measured by thermometer, hygrometer and anemometer respectively. This analysis was performed on a personal computer with Microsoft Excel 2007 version.

\section{RESULTS}

\subsection{Status of viable fungi in different room of the heritage building in different season}

Out of twenty sampling point the highest fungal spore was found at library at monsoon followed by manuscript room and entry gate throughout the season (Table 1 and Fig. 1).

Table 1. Status of viable fungi in different room of the heritage building in different season.

\begin{tabular}{|c|c|c|c|c|}
\hline $\begin{array}{c}\text { Room } \\
\text { No. }\end{array}$ & Name of sampling site & $\begin{array}{c}\text { Spore/Cubic meter } \\
\text { (Summer season) }\end{array}$ & $\begin{array}{c}\text { Spore/Cubic meter } \\
\text { (monsoon season) }\end{array}$ & $\begin{array}{c}\text { Spore/Cubic } \\
\text { meter } \\
\text { (winter season) }\end{array}$ \\
\hline S1 & Entry Room & 1655 & 1187 & 1102 \\
\hline S2 & $\begin{array}{c}\text { Manuscript preservatiorn } \\
\text { room }\end{array}$ & 1527 & 1187 & 1273 \\
\hline S3 & Museum lounge & 720 & 318 & 933 \\
\hline S4 & Living Room 1 & 1187 & 678 & 1357 \\
\hline S5 & Study Room & 1102 & 827 & 424 \\
\hline S6 & Kitchen & 636 & 1315 & 1611 \\
\hline S7 & Dining Room & 636 & 1951 & 1357 \\
\hline S8 & Music room & 764 & 1569 & 593 \\
\hline S9 & Living Room 2 & 806 & 1527 & 1060 \\
\hline S10 & Living Room 3 & 806 & 1951 & 1102 \\
\hline S11 & Living room 4 & 509 & 1018 & 84 \\
\hline S12 & Art Gallery (Bengal School) & 593 & 551 & 169 \\
\hline S13 & Art Gallery & 933 & 806 & 466 \\
\hline S14 & Family Maternity Room & 1655 & 1400 & 169 \\
\hline S15 & Japan Gallery & 2036 & 1229 & 975 \\
\hline S16 & Renaissance Gallery & 1018 & 1357 & 1145 \\
\hline S17 & Exhibition room 1 & 1018 & 1102 & 1145 \\
\hline S18 & Exhibition room 2 & 975 & 1145 & 1273 \\
\hline S19 & Exhibition room 3 & 1187 & 1484 & \\
\hline S20 & Library & 1484 & 2588 & \\
\hline & & & & \\
\hline
\end{tabular}




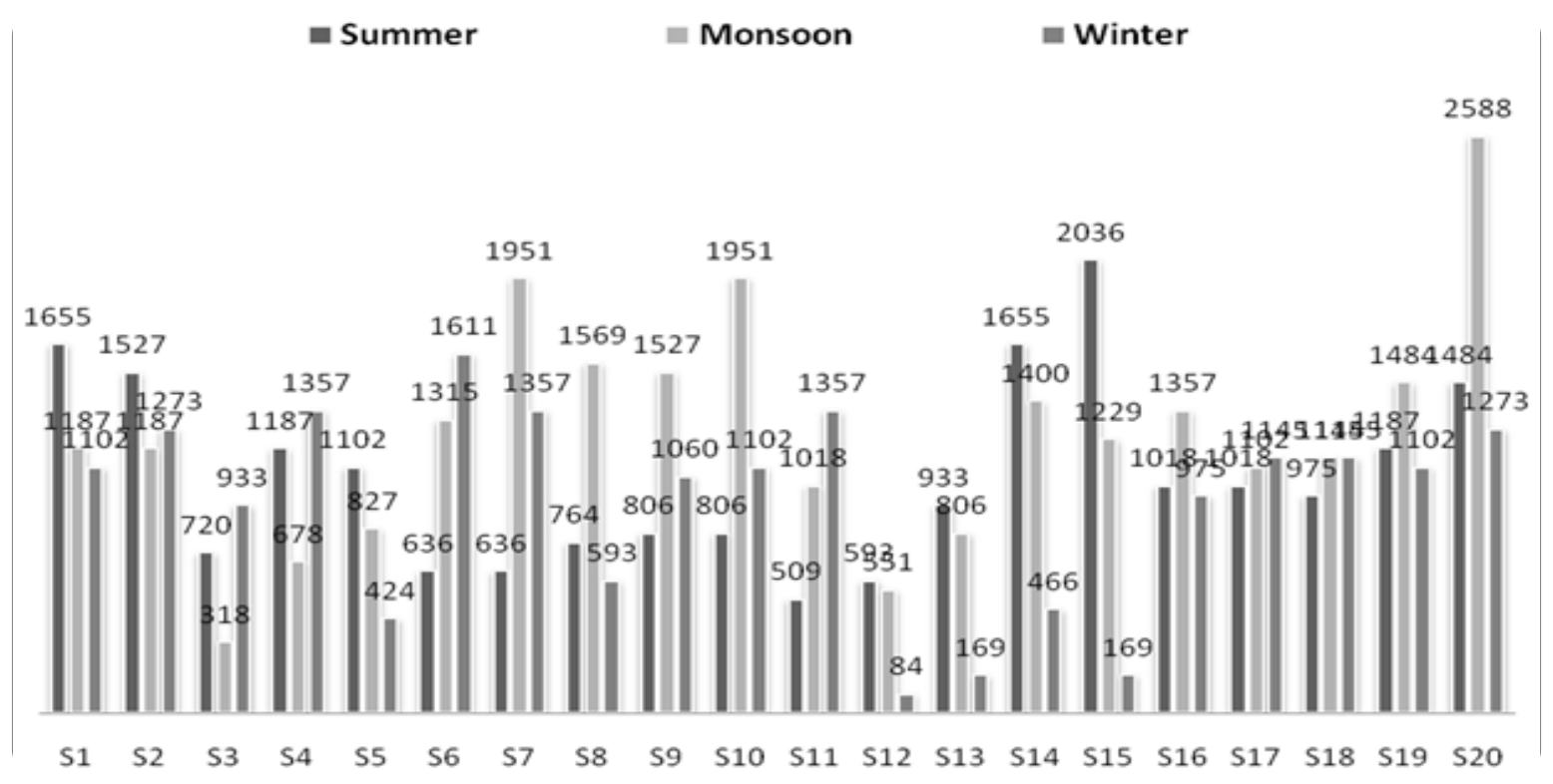

Fig. 1. Viable Spore/Cubic meter at different season.

\subsection{Status of fungal diversity in different room at different season}

Paecilomyces variotii are the dominated fungi followed by Aspergillus sp. and Penicillium $s p$ in all season and also in twenty sampling sites(Fig 2). Other fungi like Alternaria sp., Helminthosporium sp., Curvularia sp. and Yeast are found throughout the season in moderate load. Trichoderma $s p$ is only found in monsoon while Fuserium $s p$ is found only in winter season. Cladosporium sp and Verticillium sp are found only in monsoon season in least amount (Fig 2).

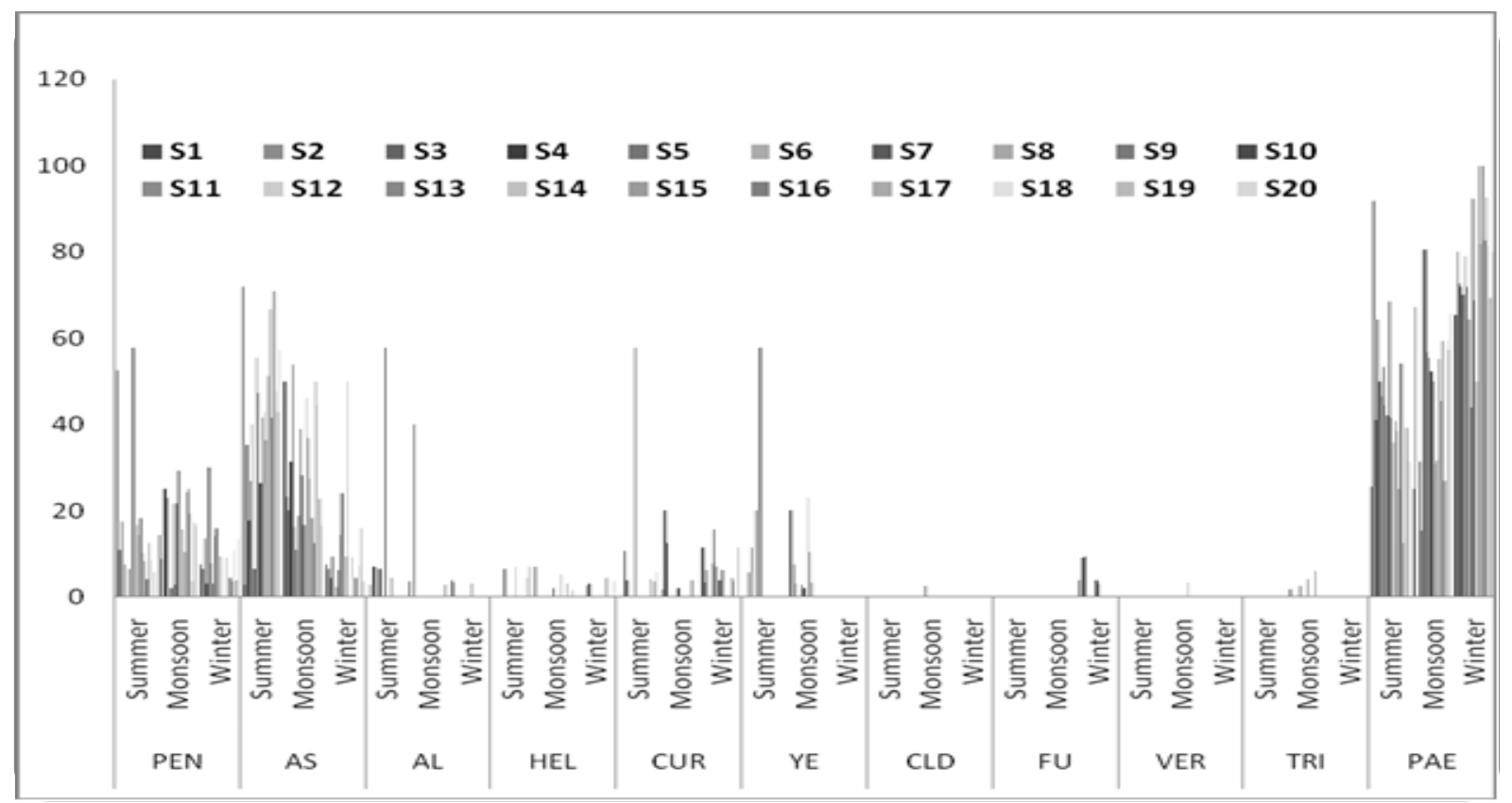

Fig. 2. Fungal diversity in different season at different sampling site. 


\subsection{Status of temerature, humidity, light and air flow in different sampling sites}

The sampling site S1 i.e. Entry gate shows the lowest temperature in both winter whereas sampling site S13 i.e. Art Gallery (Western) shows the lowest temperature in summer. The family maternity room (S14) shows the lowest temperature at monsoon (Fig 3). The highest humidity is recorded in monsoon season in four rooms of the building namely S1(Entry Room ),S5 (Study Room ), S6 (Kitchen ) and S14 (Family Maternity Room )of the building. The highest humidity is recorded in summer is in S8 (Music room) where as in winter highest humidity is found in S11 i.e. Living room 4 (Fig 4).

The highest air flow are found at entry gate (S1) in summer, dry monsoon and winter season. In wet monsoon the highest air flow are found at Dining room (S7) and Living room-2 (S9) (Fig 5).

The highest luminance is found in entry gate (S1) in three seasons. Almost same luminance as winter season is found at Renaissance Gallery (S16).

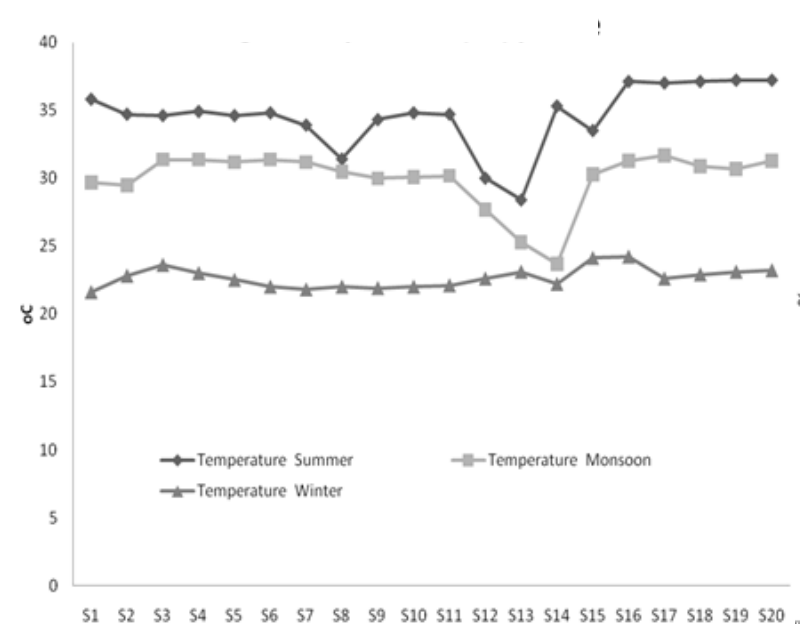

Fig. 3. Temperature (oC) profile.

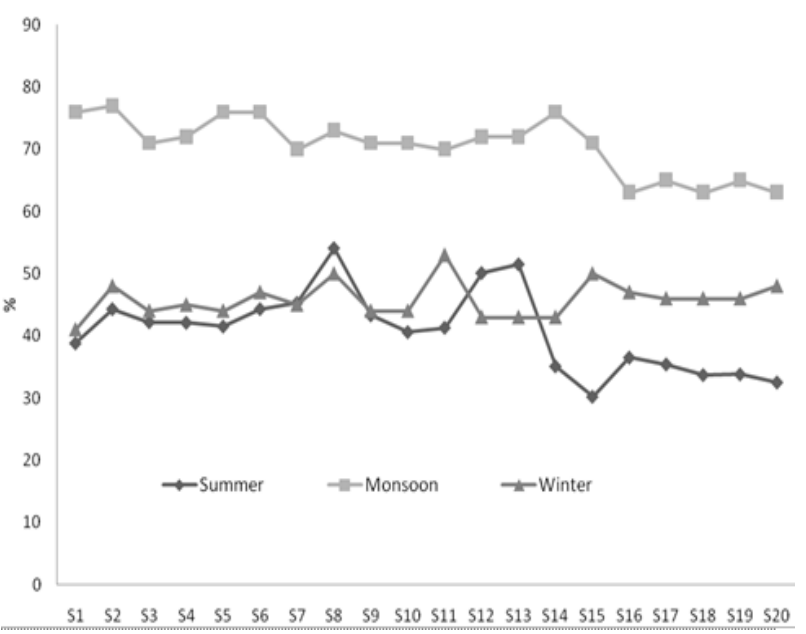

Fig. 4. Humidty profile.

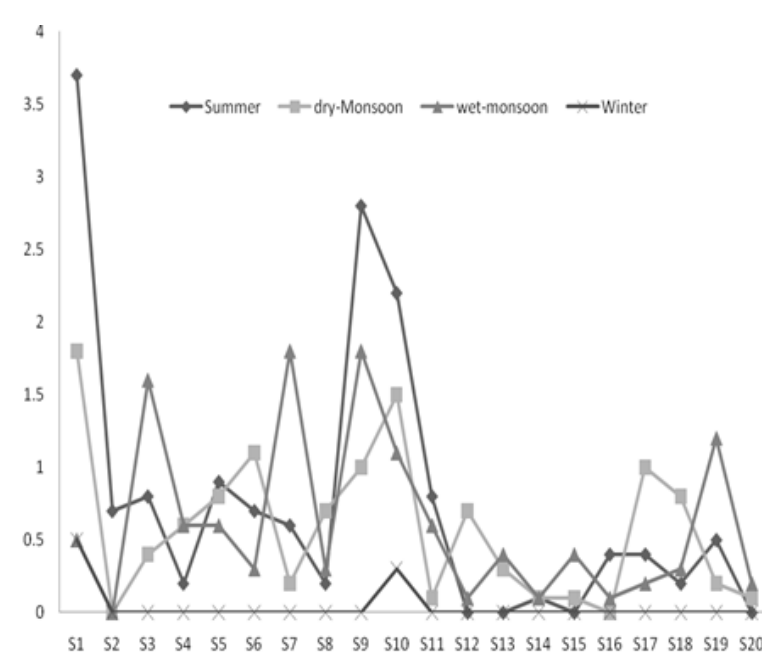

Fig. 5. Air Flow (Km/Hr).

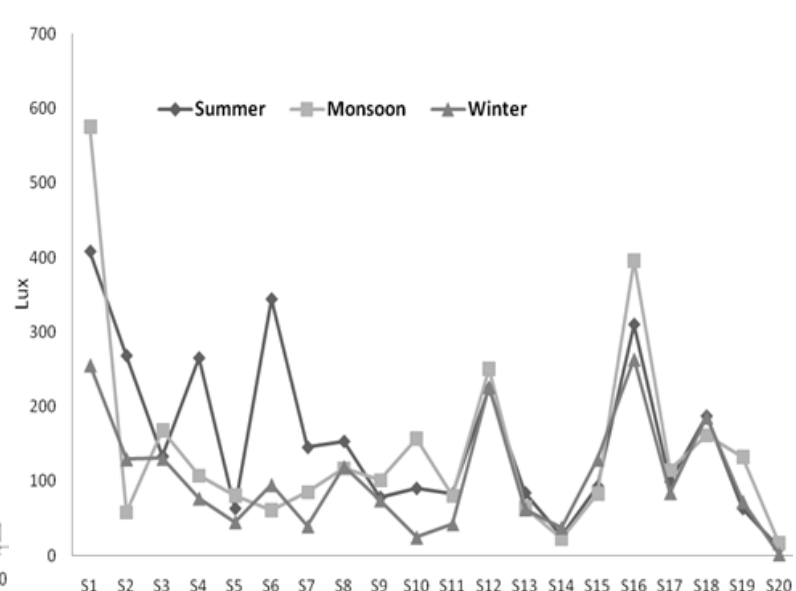

Fig. 6. Luminance (Lux) profile. 


\section{DISCUSSIONS}

In the present study, we demonstrated considerable numbers of fungi in the air of the heritage building, Kolkata West Bengal. The fungal species isolated from air were Aspergillus sp., Penicillium sp., Paecilomyces sp., Trichoderma sp, Alternaria sp Verticillium sp, Fuserium sp, Cladosporium sp, Yeast sp, Curvularia sp. and Helminthosporium sp. We performed the study round the year. In the literature there is clear evidence of seasonal differences in the numbers of fungi in indoor air. We did not assess symptoms of allergy in workers in the heritage buildings and the visitors of this place. Almost similar findings also described by Krajewska-Kułak [4] in a Tobacco factory in Kavala, Greece. The highest number of viable fungal spore was detected in the library room of the study site and the diversity throughout the year was also found highest at the same place. A study on mycological contamination at an archive facility conducted by Krysińska-Traczyk [15] revealed a large number of mould species: Peniciullium genus, Cladosporium herbarum, Geotrichum candidum, Cephalosporium glutineum, Mucor racemosus, Trichoderma viride, and Aspergillus niger in dust samples collected from the contaminated books.

The isolated fungi of indoor atmosphere Kolkata was diverse and some fungi like Fusarium sp. was found only at winter (Fig 2) where as Paecilomycessp., Aspergillus sp. and Penicillium $s p$ were found in all season in twenty sampling sites (Fig 2). This data has similarities with the observation of Garrett et al. (1998) where in indoor environment Fusarium sp. was found at winter and children living in that study site were more likely to suffer from respiratory symptoms. In the current study the other climatic factors like wind speed, temperature variation, and also the relative humidity were not varying as compare to the outdoor study. Some outdoor atmospheric study revealed that the relationship between seasonal fluctuation in airborne fungal spore concentration (dependent variable) and meteorological factors [16]. According to and Kasprzyk [17] in tropical and subtropical regions airborne viable fungal spore concentrations were reported highest during the winter and lowest during the summer. This information contradicts the present observation which revealed that most isolated fungal load were high at monsoon followed by summer season. This is probably in indoor environment the summer and monsoon season are humid (Fig 4) but the average temperature (Fig 3) varied from 27 to $30{ }^{\circ} \mathrm{C}$. This condition might helpful to grow fungal species in indoor environment. Almost similar observation has been found in rural West Bengal where the isolated fungal species are pathogen in indoor environment and causing allergen of the people.

It is interesting that the current isolated species were also pathogen to the pupae and adults insect. As the building is now used as museum and lot of exhibits including paper, silk fabric and wood materials were present in the indoor environment. Biodeteriorating agents like the larvae of some wood-boring insects, such as the furniture beetle (Anobium punctatum), may tunnel through objects and can stay there at least five years. The insect pathogenic fungi such as Verticillium sp., Aspergillus sp. and Penicillium sp. [18] were present in the study area might also harm the worker and visitors of the buildings.

\section{CONCLUSION}

In conclusion, the main fungal pathogens isolated from the air samples of the tested heritage buildings and museum were Aspergillus sp., Penicillium sp. and Paecilomyces sp. No significant correlation among number of fungal colony, wind speed and temperature in the 
tested indoor environment was noted whereas, the humidity in indoor environment played a crucial role in fungal diversity. The isolated fungi probably pathogenic in nature and create health problems.

\section{Acknowledgements}

The authors would like to thank University Grant Commission, New Delhi, India for funding (F. No 42438/2013(SR) dated 12-03-2013) and Bose Institute, Kolkata, India for technical assistance.

\section{References}

[1] MoUD, www.urbanindia.nic.in (2013).

[2] CRC, Griffith University, Queensland (2007).

[3] T. Husman, Proc Healthy Buildings, 3(2000)13-24.

[4] E. Krajewska-Kułak, C. Łukaszuk, A. Chadzopulu, S. Bousmoukilia, E. Terovitou, C. Theodosopoulou, A. Amanatidou, D. Danilidis, Progress in Health Sciences 1(1) (2011) 21-26.

[5] A.A. Andersen, American Industrial Hygiene Association Journal 27 (1966) 260 265.

[6] K. Abe, International Biodeterioration and Biodegradation 64(2010)32-40.

[7] J.D. Miller, IAQ '92, Environments for people. M. Geshwiler (ed.). ASHRAE, Atlanta, GA, 1993, p. 147-162.

[8] T. Smid Schokkin, , E. Boleij, J.S. D. Heederik, American Industrial Hygiene Association Journal 50(1989) 235-239.

[9] K. Sterflinger, Fungal Biology Reviews 24(1-2) (2010) 47-55.

[10] N. Valentín, International Journal for the Preservation of Library and Archival Material, 19(2) (2007) 85-107.

[11] S .Das, S.Gupta-Bhattacharya, Environmental Monitoring and Assessment,184 (2012) 4671-4684.

[12] P. Guiamet, S. Borrego, P. Lavin, I. Perdomo, S.G.Saravia, Colloids and Surfaces B: Biointerfaces 85(2)(2011) 229-234.

[13] S. Borrego, P. Guiamet, S. Gómez de Saravia, P. Batistini, M.Garcia, P. Lavin, International Biodeterioration and Biodegradation, 64(2) (2010)139-145.

[14] K. Zielinska-Jankiewicz, A. Kozajda, M. Piotrowska, I. Szadkowska-Stanczyk, Annals of Agricultural and Environmental Medicine 15(1) (2008) 71-8.

[15] S. Chakraborty, S.K. Sen, K. Bhattacharya, Aerobiologia 16 (2000) 211-219. 
[16] A. Adhikari, M.M .Sen, S. Gupta-Bhattacharya, S. Chanda, Science of the Total Environment 326 (2004) 123-141.

[17] I. Kasprzyk, Annals of Agricultural and Environmental Medicine 15(2008) 1-7.

[18] G. Zimmermann, A.M. Huger, G.K. Regina, Insects 4 (2013) 425-446.

( Received 25 December 2014; accepted 12 January 2015 ) 